Report

\title{
Combination of Systemic and Topical Treatment for Feline Dermatophytosis: A Case Report
}

\author{
Indarjulianto Soedarmanto ${ }^{{ }^{*}}$, Yanuartono', Slamet Raharjo', Alfarisa Nururrozi', Jeffi Chandra Aji Guna' \\ 'Department of Internal Veterinary Medicine, Faculty of Veterinary Medicine, \\ Gadjah Mada University, Indonesia \\ *Corresponding author: indarjulianto@yahoo.com \\ Submitted 14 Juli 2019, Accepted 15 Januari 2020
}

\begin{abstract}
Dermatophytoses or ringworm are the most common fungal infections in dogs and cats. This zoonotic disease is called dermatophytosis. A 2 years old male Persian cat referred to the Veterinary Clinic Faculty of Veterinary medicine, Universitas Gadjah Mada with multi-focal circular non-pruritic skin lesions and hair loss mainly on the head and ears. A complete series of dermatologic tests such as Wood's light examination, direct microscopic examination, and fungal culture were performed. The cat was treated with itraconazole dosage orally for a period of 20 days and ketoconazole topical for 35 days, respectively. Thirty five days after treatments the cat showed reduction of lesions.

Keywords: Persian cat, dermatophytoses, itraconazole, ketoconazole
\end{abstract}

\begin{abstract}
ABSTRAK
Dermatofitosis atau ringworm adalah infeksi jamur yang paling umum terjadi pada anjing dan kucing. Penyakit zoonosis ini disebut dermatofitosis. Seekor kucing Persia jantan berusia 2 tahun dirujuk ke Klinik Hewan Fakultas Kedokteran Hewan, Universitas Gadjah Mada dengan lesi kulit bukan pruritus multi-focal melingkar dan kerontokan rambut terutama di kepala dan telinga. Serangkaian tes dermatologis lengkap seperti pemeriksaan Wood's light, pemeriksaan mikroskopis, dan kultur jamur. Kucing tersebut diobati dengan itraconazole dosis per oral selama 20 hari dan ketoconazole secara topikal selama 35 hari. Tiga puluh lima hari setelah perawatan, kucing menunjukkan pengurangan lesi.

Kata kunci: kucing Persia, dermatofitosis, itraconazole, ketoconazole
\end{abstract}




\section{INTRODUCTION}

In companion animals, the skin diseases could be due to parasitism, bacterial, dermatophyte fungi, allergies, immunologic diseases, nutritional related dermatosis, hormonal disorders, and some skin cancers (Malinovschi et al. 2009). Dermatophytoses are the most common fungal infections in dogs and cats (Khosravi and Mahmoundi 2003), highly contagious but not life-threatening, treatable and curable, easily contracted by direct contact and of zoonotic importance (Moriello 2014). These fungi are classified according to their habitat in anthropophilic, geophilic, and zoophilic (Mattei et al. 2014). The main etiological agents are Microsporum canis, Microsporum gypseum and Trichophyton menthagrophytes (Lewis et al. 1991). A wide variety of dermatophytes have been isolated from animals, but the most common are Microsporum canis and Trichophyton mentagrophytes (Chermette et al. 2008). In domestic dogs and cats Trichophyton mentagrophytes is the third most common agent causing dermatophytosis, after Microsporum canis and M. gypseum (Pier and Moriello 1998; Soedarmanto et al. 2014). In captive settings, infections are usually associated with contact with humans or domestic pets.

The epidemiology of the dermatophytes is closely connected to its environment (Mattei et al. 2014). Hair is infected after exposure to fungal spores in the environment or from another animal, usually a cat. The disease usually affects younger cats, and it is presumed that the lower prevalence in older ones is because of acquired immunity through repeated exposure. These fungi share the ability to utilise keratin as a nutrient substrate, and the infection of keratinised tis (Sparkes et al. 1993). The skin lesions that appear are variable and do not necessarily form a ring. There will be hair loss, usually in small patches at first. There might be scratching due to itchiness. These infections are characterized principally by multifocal alopecia and scaling (Quinn et al. 2002). The diagnosis of dermatophytosis is unreliable on the basis of clinical signs exclusively, not only due to the variable nature of the dermatological findings, but also because there are several other skin diseases that mimic the typical dermatophytic lesion (Copetti et al. 2006). The laboratory identification of etiologic agents was based on micro and macroscopic characteristics. In addition, the urease and the in vitro hair perforation tests, the evaluation of nutritional requirements in culture, sugars assimilation, capability to growth at $37^{\circ} \mathrm{C}$ and the ability to produce germ tubes were also carried out to differentiate fungal species (Foil 1990). The antifungals commonly used in systemic treatment of dermatophytosis in dogs and cats include itraconazole, terbinafine and griseofulvin (Gupta and Del Rosso 2000).

\section{CASE HISTORY}

A 2-year-old male persian cat weighing $2 \mathrm{~kg}$ with suspected dermatophytosis was presented to the Veterinary Clinic Faculty of Veterinary medicine, Universitas Gadjah Mada. Physical examination revealed a patches of scalp hair loss, scaling, scratching, crusting the head and there is alopecia on the head and ears. Wood's lamp examination looks for fluorescence on the hair shafts infected hairs and showed green fluorescent on the head and ears. Examination with $10 \%$ potassium hydroxide $(\mathrm{KOH})$ were negative for hyphae, microconidias and macroconidias. Complementary laboratory blood tests showed that the cat had no blood abnormalities as there was no other evidence of disease. Specimens taken from scraping lesions were inoculated onto Sabouraud dextrose agar and incubated at room temperature. After 7 days incubation, growth culture on Sabouraud dextrose were taken for microscopic examination to confirm the definitive diagnosis. In this case, we used a combination of oral and topical antifungal. The cat was treated for dermatophytosis with itraconazole $10 \mathrm{mg}$ orally, once daily for 20 days and ketoconazole topical twice a day for 35 days, respectively.

\section{RESULTS AND DISCUSSION}

Physical examination revealed a patches of scalp hair loss, scaling, scratching, crusting the head and there is alopecia on the head and ears (Fig. 1). Classic lesions include one or more areas of partial alopecia with scaling and crusting most commonly on the head or forelimbs and lesions may be hyperpigmented (Moriello 2004). Diagnosis of dermatophytosis in this case was based on history, clinical examination and complementary aids, such as Wood's light, light microscope and fungal culture. In this case, Wood lamp examination showed green fluorescent on the head and ears (Fig. 2).

These results indicated that the fluoresence probably due to dermatophyte species including $M$. canis. According to Outerbridge (2006), when exposed to the light, hairs invaded by most of $M$. canis 


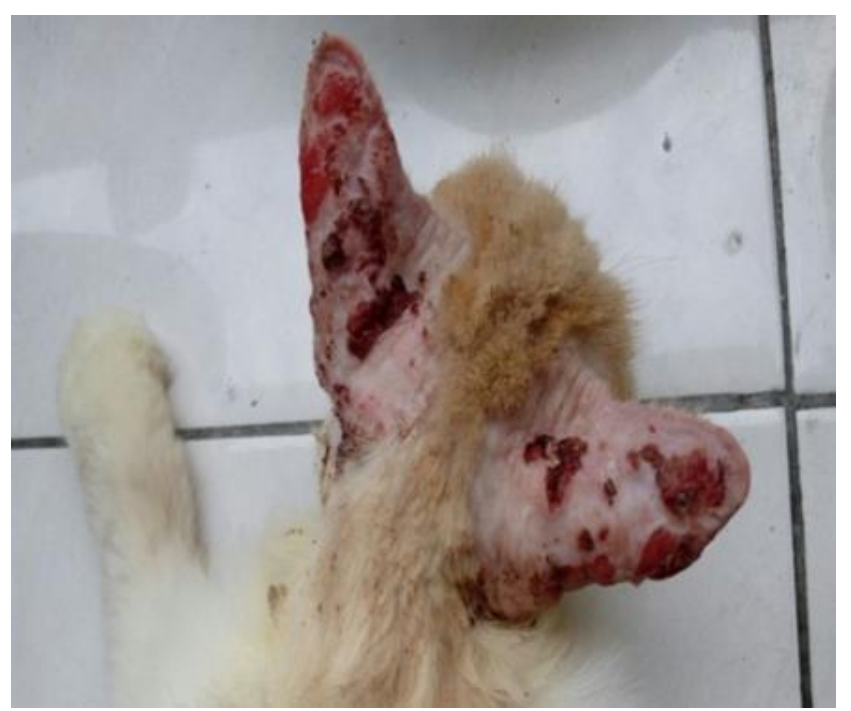

Figure 1 A patches of scalp hair loss, scaling, scratching, crusting, and alopecia on the ears

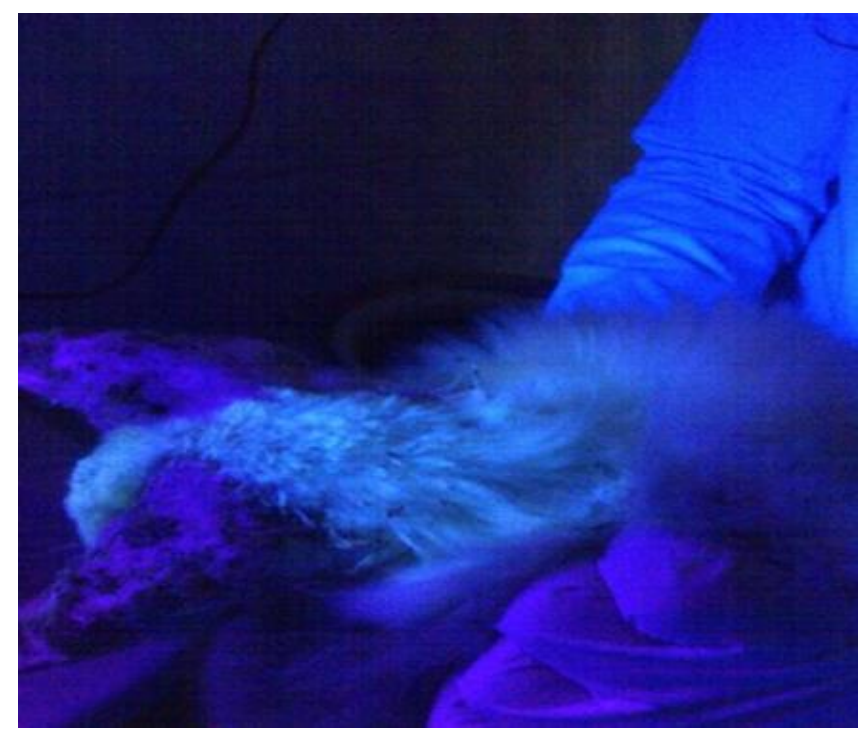

Figure 2 Green fluorescent on the head and ears

showed glow yellow green. However, the green fluorescene not only due to $M$. canis but also came from other materials. According to Gupta and Singh (2004) the Wood's lamp is useful in establishing a tentative diagnosis of dermatophytosis in dogs and cats but cannot be used to exclude this type of infection since some skin ointments and other materials will fluoresce and may give a false positive result. Therefore, examination with an ultraviolet lamp (Wood's lamp) was only used for screening method for dermatophytosis. Mycological culture remains the most reliable technique for confirming dermatophytosis in cats.
The samples were subjected to native light microscopy for detection of fungal elements (hyphae and arthrospores) after preliminary treatment with $10 \% \mathrm{KOH}$. The result of examination with $10 \% \mathrm{KOH}$ were negative for for hyphae, microconidias and macroconidias. Nevertheless, these results could be false negative. Microscopic identification of fungal elements directly in clinical samples using potassium hydroxide $10 \%(\mathrm{KOH})$ is a quick method, but its specificity and sensitivity is low. Moreover, false negative results are possible. According to Levitt et al. (2010) the sensitivities for $\mathrm{KOH}$ smear and culture were $73.3 \%$. 
In this case, definitive diagnosis is made by fungal culture and was considered the "gold standard" for diagnosis. The most commonly used fungal culture media was Sabouraud's dextrose agar. Culture of the clinical specimen placed on Sabouraud dextrose agar showed a flat colony, white to cream in colour, with a powdery to granular surface (Fig. 3). These characters were like Trichophyton mentagrophytes. Weitzman and Summerbell (1995) noticed that the colony of Trichophyton mentagrophytes were plane, white to cream color, powdery to granular surface and reverse yellowish brown to reddish-brown in Sabouraud dextrose agar at $25^{\circ} \mathrm{C}$. According to De Hoog et al. (2000), this fungi can be phenotypically identified through different tests, where, for instance, T. mentagrophytes is always urease-positive, unfortunately, in this case urease test was not performed. The isolates were examined for microscopic morphology using lactophenol cotton blue staining and the result showed macroconidias (Fig. 4). Although urease test was not performed, however, from microscopic examination we suggested that the culture was Trichophyton mentagrophytes.

In this case, combination of systemic and topical treatment were used on the basis of mycological analysis results and the clinical signs. A systemic oral therapy with itraconazole at a dose of $10 \mathrm{mg} / \mathrm{kg}$, and topical treatment with ketoconazole twice a day. Borgers et al. (1993) suggested that topical therapy alone does not adequately penetrate the hair follicle and that optimal treatment of dermatophytosis caused by species that invade the hair follicle and

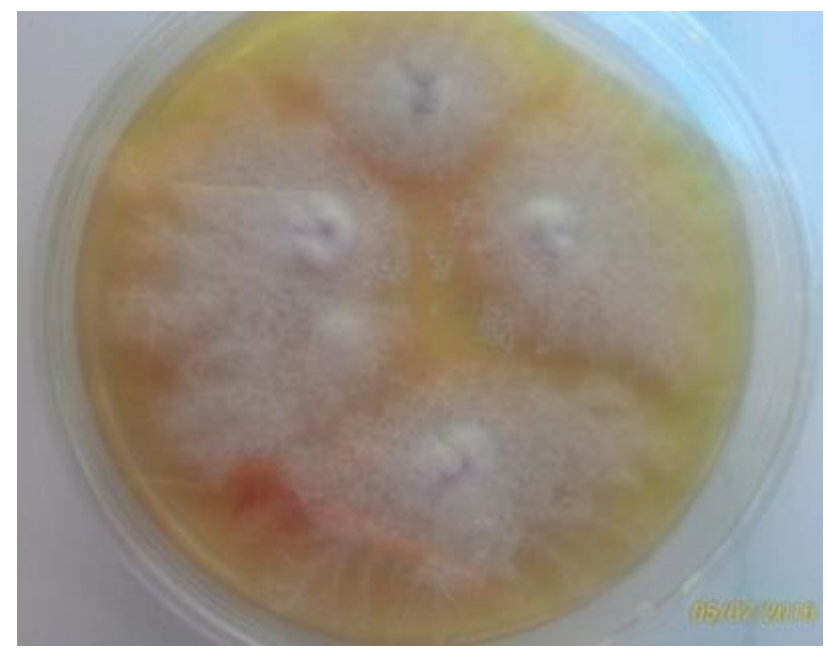

Figure 3 Sabouraud dextrose agar showed a flat colony, white to cream in colour, with powdery to granular surface

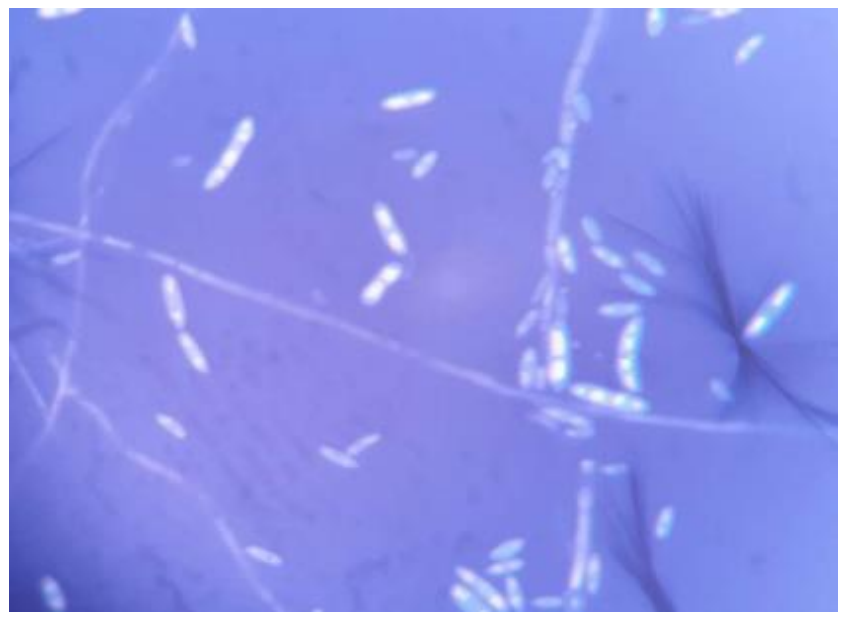

Figure 4 Lacto phenol cotton blue mount showing macroconidias 
hair shaft (such as $M$. canis) requires systemic therapy for effective penetration to this site. After treated with itraconazole for 20 days and ketoconazole for 35 days respectively, the cat showed reduction of lesions (Fig. 5). According to Bond (2010), The treatment must be extended over 2 to 4 weeks after clinical cure and after obtaining two or more negative fungal cultures. Complete resolution was achieved after 42 days of itraconazole and ketoconazole treatment.

\section{ACKNOWLEDGEMENTS}

Researchers would like to thank the Faculty of Veterinary Medicine, Gadjah Mada University, Indonesia, as well as General of Higher Education, Ministry of Education and Culture, Indonesia for financial support.

"All authors declare that there are no conflicts of interest".

\section{REFERENCES}

Borgers M, Xhonneux B, Van Cutsem J. 1993. Oral itraconazole versus topical bifonazole treatment in experimental dermatophytosis. Mycoses. 1993 Mar-Apr. 36(3-4): 105-15.

Bond R. 2010. Superficial veterinary mycoses. Clinics in Dermatology. 28(2): 226-36.

Chermette R, Ferreiro L, Guillot J. 2008. Dermatophytoses in animals. Mycopathologia. 166 (5-6): 385-405.

Copetti MV, Santurio JM, Cavalheiro AS, Boeck AA, Argenta JS, Aguiar LC, Alves SH. 2006. Dermatophytes isolated from dogs and cats suspected of dermatophytosis in Southern Brazil. Acta Scientiae Veterinariae. 34(2): 119-124.

De Hoog GS, Guarro J, Gene' J, Figueras MJ. 2000. Atlas of Clinical Fungi, $2^{\text {nd }}$ edn. Utrecht: Centraalbureau voor Schimmelcultures.

Foil CS. 1990. Dermatophytosis. In: Greene C.E. (Ed.). Infectious Diseases of the Dog and Cat. Philadelphia: W.B. Saunders, 659-668.

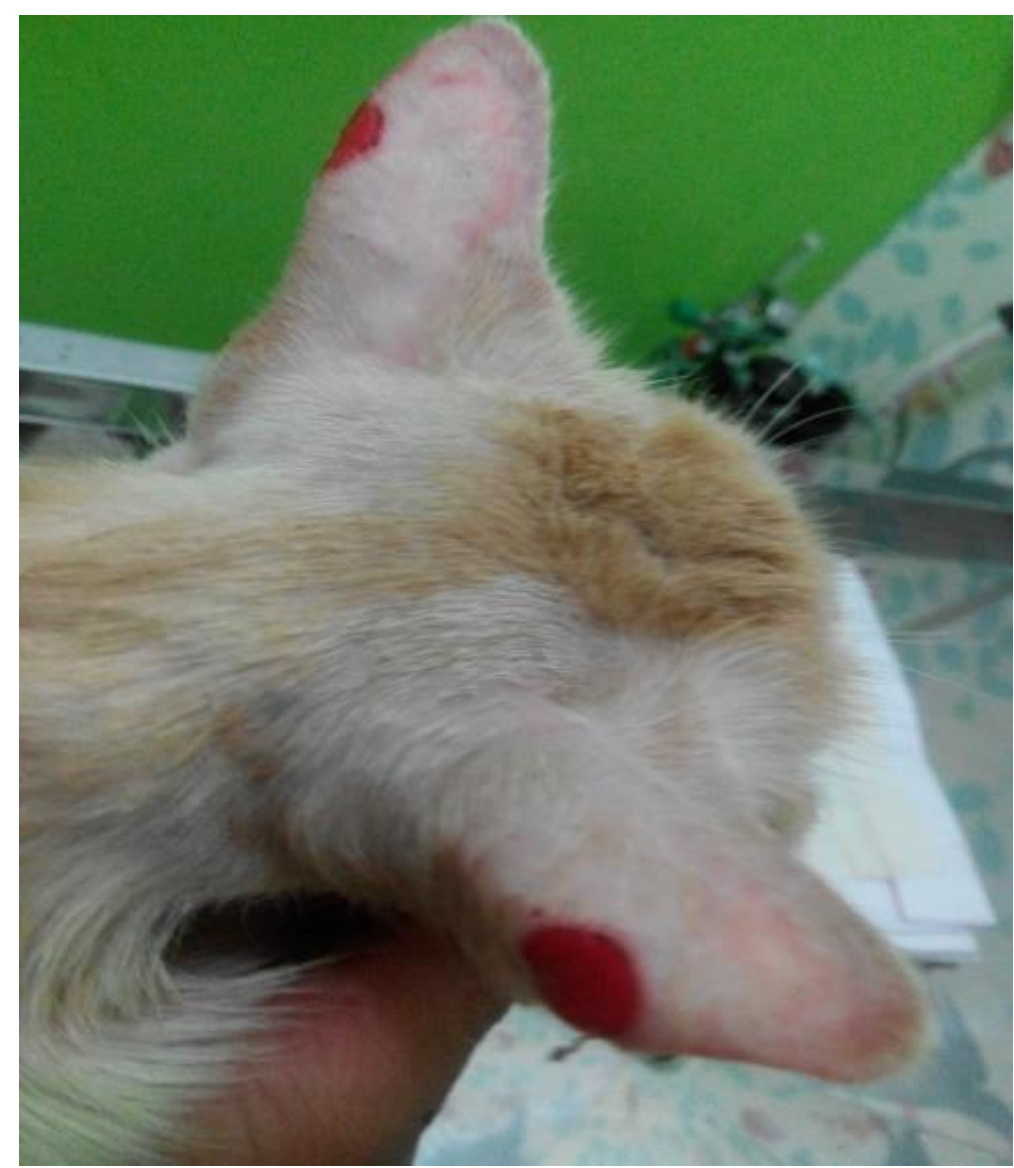

Figure 5 Thirty five days after combination treatments with itraconazole and ketoconazole for 35 days 
Gupta LK, Singhi M. 2004. Wood's lamp. Indian J Dermatol Venereol Leprol. 70: 131.

Gupta AK, Del Rosso JQ. 2000. An evaluation of intermittent therapies used to treat onychomycosis and other dermatomycoses with the oral antifungal agents. Int. J. Derm. 39: 401-411.

Khosravi AR, Mahmoundi M. 2003. Dermatophytes isolated from domestic animals in Iran. Mycoses 46: $222-225$

Levitt JO, Levitt BH, Akhavan A, Yanofsky H. 2010. The sensitivity and specificity of potassium hydroxide smear and fungal culture relative to clinical assessment in the evolution of tinea pedis: a pooled analysis. Dermatol Res Pract. 2010: 1-8.

Lewis DT, Foil CS, Hosgood G. 1991. Epidemiology and clinical features of dermatophytosis in dogs and cats at Louisiana State University: 1981-1990. Veterinary Dermatology. 2: 53-58.

Malinovschi G, Kocsubé S, Galgóczy L, Somogyvári F, Vágvölgyi C. 2009. Rapid PCR based identification of two medically important dermatophyte fungi, Microsporum canis and Trichophyton tonsurans. Acta Biol Szeged. 53(1): 51-54

Mattei AS, Beber MA, Madrid IM. 2014. Dermatophytosis in small animals. Symbiosis. 2(3): 1-6

Moriello KA. 2004. Treatment of dermatophytosis in dogs and cats: review of published studies. Vet Dermatol. 15: 99-107,
Moriello KA. 2014. Feline Dermatophytosis Aspects pertinent to disease management in single and multiple cat situations. Journal of Feline Medicine and Surgery. 16: 419-431

Outerbridge CA. 2006. Mycologic Disorders of the Skin. Clin Tech Small Anim Pract. 21: 128-134 (C) Elsevier Inc.

Pier AC, Moriello KA. 1998. Parasitic relationship between Microsporum canis and the cat. Med Mycol. 36: 271-275.

Quinn PJ, Markey BK, Carter ME, Donnelly WJ, Leonard FC. 2002. Veterinary Microbiology and Microbial Disease. Iowa: Blackwell Publishing Professional.

Sparkes AH, Gruffydd-Jones TJ, Shaw SE, Wright Al, Stokes CR. 1993. Epidemiological and diagnostic features of canine and feline dermatophytosis in the United Kingdom from 1956 to 1991. Veterinary Record. 133: 57-61

Soedarmanto I, Purnamaningsih H, Raharjo S, Yanuartono, Ikliptikawati DK, Sakan GIY. 2014. Isolation and Identification of Microsporum canis from Dermatophytosis Dogs in Yogyakarta. Jurnal Veteriner. 15 (2): 212-216

Weitzman I, Summerbell R. 1995. The Dermatophytes. Clinical Microbiology Reviews. 8(2): 240259. 